\title{
Quality Assurance, Safety and Acceptability of Odourless Fufu Flour Produced from White and Yellow-Flesh Cassava using NSPRI-Technology
}

\author{
Kunle Ogungbemi ${ }^{1}{ }^{2 *}$, Segun Samuel Ajisafe ${ }^{1}$, Bukola Balogun ${ }^{1}$, Daniel Adeiza Balogun ${ }^{3}$, \\ Funmilayo Florence Ilesanmi ${ }^{1}$, Abolanle Omolola Ilori ${ }^{1}$
}

\begin{abstract}
Fufu is one of the major fermented cassava food product widely consumed in Nigeria. Due to several unhygienic methods of preparation and objectionable odour, this study was carried out to investigate the nutritional, cyanide, rheological and microbial properties of odourless $f u f u$ flours produced from white and yellow flesh cassava using Nigerian Stored Products Research Institute (NSPRI) Technology and sensory properties of smooth dough prepared from the reconstituted flours. The results showed that both white and yellow odourless fufu has safe moisture content $(4.34$ to $7.21 \%)$. It was also observed that white and yellow odourless fufu had an improved pasting properties with pasting temperature and viscosity of $\left(71.85^{\circ} \mathrm{C}\right.$ to $75.23^{\circ} \mathrm{C}$ and $\left.3088 \mathrm{cp}-3797 \mathrm{cP}\right)$, The Cyanide content and microbial analysis of both flours were within the safe range with no coliform bacterial present. The sensory evaluation from panelists showed that white odourless fufu had a better overall acceptability despite yellow flesh having higher ascorbic acid and $\mathbf{T}$. carotenoid content. From the study, it can be concluded that the cyanide content, microbial load of the processed flour samples using NSPRI technology were at a safe level. Which makes it safe for consumption and the level of moisture content of the flours would make the flours suitable for long term storage.
\end{abstract} flours.

Keywords: cassava, dryer, food safety, quality, fufu-

\section{INTRODUCTION}

Cassava (Manihot esculenta crantz) is cultivated solely for its storage roots (Nweke, 1996). It is a staple food for over 500 million people in the developing countries of the world (Vimala, Thushara and Nambisan, 2010). The cassava plant gives the thirdhighest yield of carbohydrates per cultivated area among crop plants, after sugarcane and sugar beets, which makes it a major food crop. In Nigeria, cassava is an important food crop cultivated in large quantity. The nation is the leading producer of cassava in the world with a yearly production of above 40 million tonnes (Owolarafe et al., 2018; Eguono, 2015). As a result of large production and its susceptibility to rapid postharvest physiological deterioration, thus, reducing postharvest loss, several crops are either dried and stored before usage as seen in Ogungbemi et al., (2017) where leafy vegetable are dried stored or processed into other food items like cassava being converted into fufu, gari, lafun among others (Ayetigbo et al., 2019). In the areas where cassava is cultivated, the flesh color is traditionally white (Vimala et al., 2010). This is typically significant to produce "white" starch or high quality flour. However, other colored-flesh cassava variants (yellow, orange, cream, and red) have emerged to refute this supposition (Ayetigbo et al., 2018). Whiteflesh (and other dull colored) cassava have negligible carotenoid content compared to yellow-flesh cassava (Montagnac, Davis and Tanumihardjo, 2009; Gegios et al., 2010). Cassavas with deeper colour intensity have higher carotene content (Chavez et al., 2000; Ceballos et al., 2013). Visual differences also exist between root and flour of white-flesh and yellow-flesh variants, but not for the starch ( $\mathrm{Gu}$ et al., 2013; Ayetigbo et al., 2018). Conversely, challenges have arisen from poor knowledge of nutritional benefits of the colored-flesh cassava, misinformation about the nature of development of the cassava as genetically modified crops, unwillingness of farmers to change cultivation pattern and consumers to accept the end-products, this could be as a result of inadequate dissemination of information about the variant. Fufu (also known as utara akpu) is wholly carbohydrate based food item obtained from peeled soaked fermented cassava roots. Traditionally, it is produced in wet form with moisture content of $40-50 \%$. This makes the product highly perishable compared with 'gari' and 'lafun', which are in granular form with moisture content below $10 \%$, which is reconstituted by stirring in boiling water to form dough and eaten with flavoured sauces (Owolarafe et al., 2018). In some areas, low cyanide cassava roots can be boiled or steamed and pounded into fufu (Hahn, 1988; Bamidele et al., 2015). In addition, one of the

DOI: 10.21608/asejaiqjsae.2021.176110

${ }^{1}$ Chemistry/Biochemistry Unit, Nigerian Stored Products Research Institute, Ibadan, Oyo State

${ }^{2}$ Department of Biochemistry, Federal University of Agriculture, Abeokuta.Ogun State.

${ }^{3}$ Microbiology Unit, Nigerian Stored Products Research Institute, Ibadan, Oyo State.

Correspondence Email: kunleoguns484@gmail.com

Tel: +234(0)8066970191

Received May 10, 2021, Accepted, June 07, 2021. 
major problems in processed fufu is the odour of the product, which may be undesirable to a lot of people. Another problem with fufu production is that the quality of the product differs with processors and from one processing batch to the other by the same processor. Factors that could be responsible for the difference in quality of $f u f u$ include; the size to which the roots are cut prior to soaking (Okafor et al., 1984), variety differences in dry matter content and the quality of roots or water used for soaking and at large, the technologies adopted.

Due to these challenges, the Nigerian Stored Products Research Institute (NSPRI) has been intervening in promotion of its improved multi-crop dryer for hygienic, clean and effective drying of agricultural produce. It is also developed to preserve the nutritional qualities of the produces, as well as extending their shelf lives.

\section{MATERIALS AND METHODS}

\section{Materials}

The freshly harvested white flesh and yellow flesh cassava roots used were procured from Tropical Agricultural, Nigeria with a batch number 1WDC2SYN and Nigeria. All chemicals used were of analytical grade.

\subsection{Preparation of odourless fufu flour}

Cassava roots (both white and yellow flesh) were sorted, cleaned, peeled and washed in running portable water to remove extraneous materials, sliced into pieces before further processing in to flours. Odourless flours preparation was carried out according to the procedure of Achi and Akomas (2006). The cassava was sliced to reduce its surface area and initial soaking and partfermentation for the samples was carried out for 48 hours, before pulping and final fermentation for 24 hours. After which, the white flesh cassava and yellow flesh cassava were dried separately using NSPRI-multicrop dryer. The two samples were then homogenized into powdered form to produced odourless fufu flour.

\section{Methods}

\subsection{Determination of proximate composition}

The proximate of composition of the samples includes the moisture, crude protein, crude fat, crude fibre, ash and carbohydrate contents, which were determined according to the standard analytical method by the Association of Official Analytical Chemists (AOAC 2005). The total carbohydrate was determined by difference, according to the equation:

\section{Total carbohydrate}

$$
\begin{aligned}
& =100-(\% \text { moisture }+\% \text { fat } \\
& +\% \text { protein }+\% \text { fibre }+\% \text { ash })
\end{aligned}
$$

\subsection{Determination of cyanide content}

$100 \mathrm{~g}$ samples of cassava products were added to a small plastic bottle, a buffer/enzyme paper was added, followed by $1 \mathrm{~L}$ of $1 \mathrm{M} \mathrm{pH} 6$ phosphate buffer, a picrate paper and a screw cap lid. The bottles were allowed to stand overnight at $30{ }^{\circ} \mathrm{C}$, the picrate papers were removed from the plastic support and $5.0 \mathrm{~L}$ of water added to elute the colour. The absorbance was measured in a spectrophotometer at $510 \mathrm{~nm}$ and the total cyanide content in mg HCN equivalents/ 100g fresh weight was evaluated and values were reported in triplicate.

\subsection{Determination of vitamin $C$}

The concentration of vitamin $\mathrm{C}$ was determined by redox titration using standardized iodine solution, according to a slightly modified method described by Galani et al., (2017). Vitamin C in sample reacts with iodine to produce dehydroascorbic acid and iodide ions. Excess iodine then reacts with the starch indicator to produce violet color and indicate the end point of titration. Ascorbic acid $\mathrm{C}_{6} \mathrm{H}_{8} \mathrm{O}_{6}+\mathrm{I}_{2} \rightarrow$ Dehydroascorbic $\operatorname{acid}\left(\mathrm{C}_{6} \mathrm{H}_{8} \mathrm{O}_{6}\right)+2 \mathrm{I}^{-}$

\subsection{Determination of total carotenoids}

Total carotenoid (TC) content was determined according to De Carvalho et al., 2012 modified. $5 \mathrm{mg}$ of the sample was ground with the aid of hyflo super-cel $(3.0 \mathrm{~g})$ in $50 \mathrm{ml}$ of cold acetone and vacuum filtered. The filtrate was extracted using $40 \mathrm{ml}$ petroleum ether (PE). Saturated sodium chloride was used to prevent the formation of emulsion. The lower aqueous phase was discarded while the upper phase was collected and filtered through $15 \mathrm{~g}$ of anhydrous sodium sulfate to eliminate residual water. The separating funnel was washed with PE and the flask was made up to $50 \mathrm{ml}$. The absorbance of the solution was measured at $450 \mathrm{~nm}$ and the total carotenoid content was calculated using the Beer-Lambert law (Equation 1).

$T C(\mu g / g)=\frac{A \times V(m L) \times 104}{A^{196} 1 \mathrm{~cm} \times P(g)}$

Where $\mathrm{A}=$ is the absorbance, $\mathrm{V}=$ Total extract volume after second extraction, $\mathrm{P}=$ Sample weight, $\mathrm{A}^{1 \%} 1 \mathrm{~cm}$ $=2592$ (beta carotene extinction coefficient in petroleum ether).

\subsection{Determination of pasting properties:}

Pasting Properties of Flour and Starch The pasting properties of cassava flour and starch were examined using a Rapid Visco-Analyzer (Newport Scientific, Australia) as previously reported (Oyeyinka,et al., 2016). Briefly, samples ( $2.8 \mathrm{~g})$ were weighed into the test canister containing $25 \mathrm{ml}$ of distilled water. The mixture was agitated by mixing manually before inserting the canister into the instrument. Starch was stirred at $960 \mathrm{rpm}$ for $10 \mathrm{~s}$ before the shear input was 
decreased and held constant at $160 \mathrm{rpm}$ during the subsequent heating and cooling cycles.

\subsection{Determination of functional properties}

Bulk density of the sample was determined using the method described by Ekunseitan et al., (2017). Water absorption capacity of the sample was determined using the method described by Harouna, et al., (2019). The water absorption capacity was expressed as volume of water absorbed per gram of flour. The solubility index of the flour blend was determined using the method described by Singh et al., (2005). Dispersibility was determined by the method described by Kulkarni et al.,(1991). Swelling power was determined using the method described by Oyeyinka et al.,(2015), with slight modifications.

\subsection{Microbial Count}

The microbial count was determined using the methods of Güngör and Gökoğlu 2010 modified). The isolation of the constituting fungal colonies in the odourless fufu flour samples were carried by doing a 10 -fold serial dilution of the sample. $10 \mathrm{~g}$ each of both white flesh and yellow flesh sample were put into a $90 \mathrm{ml}$ of sterile distilled water, from this mixture $1 \mathrm{ml}$ of the aliquot was then taken and poured into a $9 \mathrm{ml}$ of sterile distilled water held in a test-tube, this process was then repeated for 6 dilution, then $1 \mathrm{ml}$ of the $10^{-1}$, $10^{-3}$ and $10^{-5}$ were plated on Potatoes Dextrose Agar (PDA), Nutrient Agar (NA) and Eosin Methylene Blue (EMB) for the enumeration of the fungal, bacterial and coliform constituent respectively using the pour plate method, the plates were then incubated at $27^{\circ} \mathrm{c}$ for $72-96$ hours for fungal growth, at $35^{\circ} \mathrm{c}$ for 24 hours for bacterial and coliform growth, however, $25 \mu \mathrm{g}$ of chloramphenicol was added to the PDA before autoclaving to prevent bacterial growth.

\subsection{Sensory evaluation}

The method as described by Saadoudi et al., (2017) was used for the sensory evaluation. Thirty panelists were selected to evaluate the reconstituted doughs for appearance, colour, aroma, taste and overall acceptability using a 9-point hedonic scale (from $1=$ extremely dislike to $9=$ extremely like). The white flesh odourless fufu flour (WOF) and yellow flesh odourless fufu flour (YOF) samples were prepared separately by reconstituting the flours into fufu. This was done by cooking and stiring the already mixed flour in water on medium heat until a smooth dough was obtained. The white flesh odourless fufu (WOF) and yellow flesh odourless fufu (YOF) were coded with random digits were randomly presented to the panelists in clear plates. Each panelist was provided with a glass of water to rinse their mouths at intervals during the evaluation period.

\subsection{Statistical analysis}

Analyses were carried out in triplicates and the data obtained were subjected to one way analysis of variance (ANOVA), using Statistical Package for Social Sciences (SPSS version 20.0 Inc.). Values were represented as Mean \pm Standard Deviation (SD), statistical differences among means were $(\mathrm{P}<0.05)$.

\section{RESULTS}

\section{Proximate composition of white and yellow flesh odourless fufu flours produced using NSPRI flour}

Table 1 shows the proximate composition of white and yellow flesh odourless fufu flours produced using NSPRI multi-crop dryer. The moisture content WOF turned out to be $4.34 \%$, but YOF had a significantly higher $(\mathrm{P}<0.05)$ moisture content of $7.21 \%$. For lipids, WOF $(2.71 \%)$ and YOF $(2.33 \%)$ were not significantly different $(\mathrm{P}<0.05)$. The crude protein, crude fibre, ash and carbohydrate contents of WOF were $2.22 \%, 3.12$ $\%, 3.10 \%$ and $84.51 \%$. But for YOF, the values 2.21 $\%, 2.84 \%, 3.11 \%$ and $82.30 \%$ for crude protein, crude fibre, ash and carbohydrate contents respectively.

Table 1. Proximate composition of white and yellow flesh odourless fufu flours

\begin{tabular}{lcccccc}
\hline PROCESSING & $\begin{array}{c}\text { MOISTURE } \\
\text { METHODS }\end{array}$ & $\begin{array}{c}\text { LIPIDS } \\
(\boldsymbol{\%})\end{array}$ & $\begin{array}{c}\text { ASH } \\
(\boldsymbol{\%})\end{array}$ & $\begin{array}{c}\text { FIBRE } \\
(\boldsymbol{\%})\end{array}$ & $\begin{array}{c}\text { PROTEIN } \\
(\boldsymbol{\%})\end{array}$ & $\begin{array}{c}\text { CHO } \\
(\boldsymbol{\%})\end{array}$ \\
\hline WOF & $4.34 \pm 1.32^{\mathrm{a}}$ & $2.71 \pm 0.12^{\mathrm{a}}$ & $3.10 \pm 0.12^{\mathrm{a}}$ & $3.12 \pm 0.21^{\mathrm{a}}$ & $2.22 \pm 0.07^{\mathrm{a}}$ & $84.51 \pm 2.12^{\mathrm{a}}$ \\
YOF & $7.21 \pm 1.12^{\mathrm{b}}$ & $2.33 \pm 0.02^{\mathrm{a}}$ & $3.11 \pm 0.11^{\mathrm{a}}$ & $2.84 \pm 0.26^{\mathrm{a}}$ & $2.21 \pm 0.02^{\mathrm{a}}$ & $82.30 \pm 3.67^{\mathrm{a}}$ \\
\hline
\end{tabular}

Values are analyzed in triplicated and represented as (Means \pm SD) with different superscript down the column being significantly different $(\mathrm{P}<0.05)$.

White flesh odourless fufu flour (WOF)

Yellow flesh odourless fufu flour (YOF) 
2. Cyanide, vitamin $C$ and Total carotenoid concentration of white and yellow flesh odourless fufu flours produced using NSPRI technolgoy

Fig. 1 shows the results of the cyanide, vitamin c and total carotenoid concentrations. Significant differences $(\mathrm{P}<0.05)$ were observed in samples WOF and YOF. The cyanide concentration of WOF was slightly higher than that of YOF. For vitamin c concentration, it was observed that the YOF had a significantly higher $(\mathrm{P}<0.05)$ concentration than WOF. This same trend was observed in the concentration of total carotenoid.
3. Pasting properties of white and yellow flesh odourless fufu flours produced using NSPRI technology

The pasting properties of the flours Table 2 revealed significant differences $(\mathrm{P}<0.05)$ in the peak viscosity of WOF and YOF, with WOF (5389 cP) having a significantly higher $(\mathrm{P}<0.05)$ peak viscosity than $\mathrm{YOF}$ $(5012 \mathrm{cP})$. A similar trend was observed in trough, final viscosity and setback, with WOF having $2817 \mathrm{cP}, 3797$ $\mathrm{cP}$ and $990 \mathrm{cP}$ respectively while YOF had $2218 \mathrm{cP}$, $3088 \mathrm{cP}$ and $765 \mathrm{cP}$ ) for trough, final viscosity and setback. But there were no significant differences observed in the pasting temperatures of the flour samples.

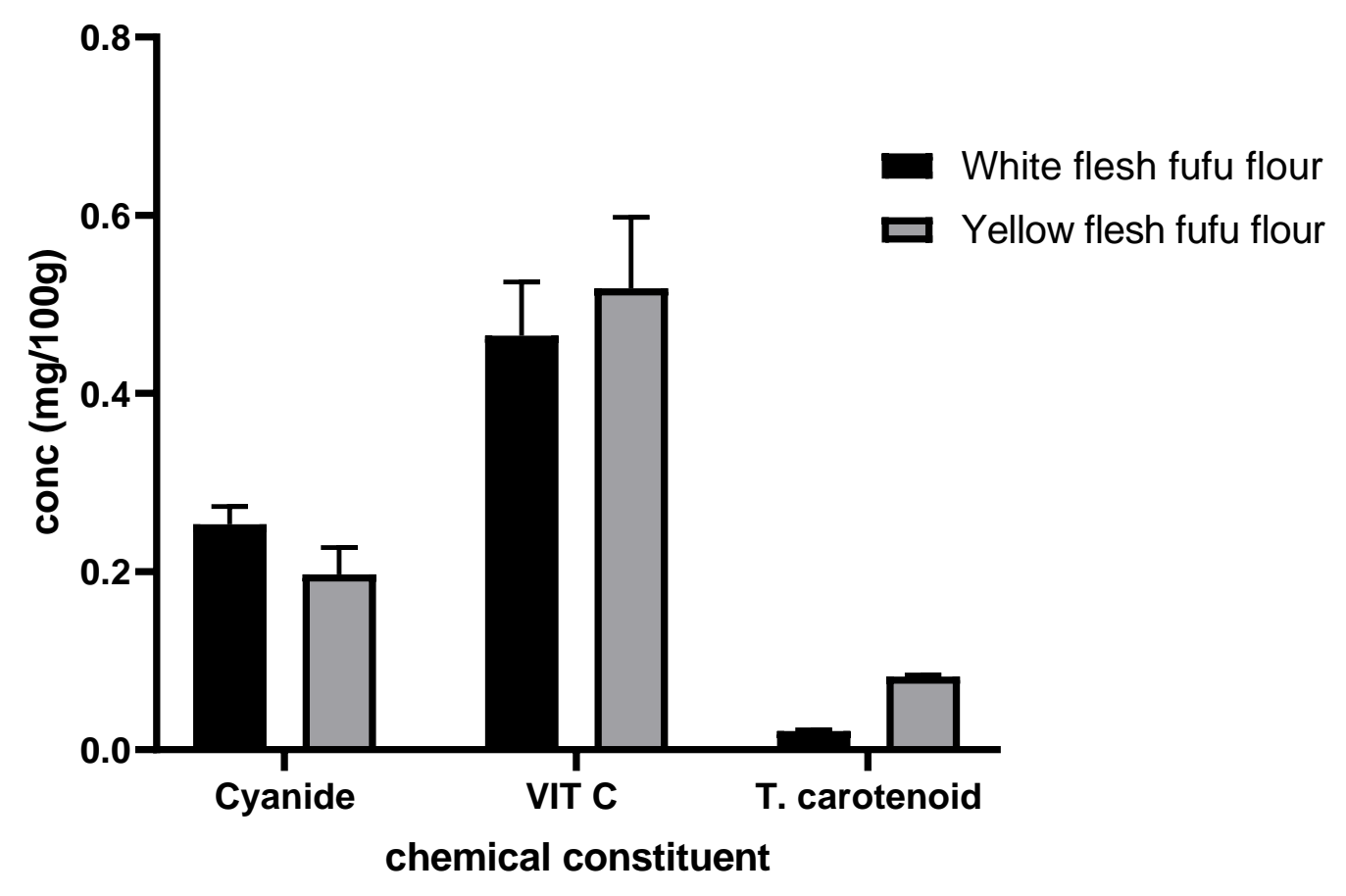

Figure 1. Cyanide, vitamin $\mathrm{C}$ and Total carotenoid concentration of white and yellow flesh odourless fufu flours

Table 2. Pasting properties of white and yellow flesh odourless fufu flours

\begin{tabular}{lccccccc}
\hline Sample & $\begin{array}{c}\text { Peak } \\
\text { viscosity }(\mathbf{c P})\end{array}$ & $\begin{array}{c}\text { Trough } \\
(\mathbf{c P})\end{array}$ & $\begin{array}{c}\text { Breakdown } \\
(\mathbf{c P})\end{array}$ & $\begin{array}{c}\text { Final } \\
\text { viscosity }(\mathbf{c P})\end{array}$ & $\begin{array}{c}\text { Setback } \\
(\mathbf{c P})\end{array}$ & $\begin{array}{c}\text { Peak Time } \\
(\text { minth })\end{array}$ & $\begin{array}{c}\text { Pasting } \\
\text { Temp }\left({ }^{\circ} \mathbf{C}\right)\end{array}$ \\
\hline WOF & $5389 \pm 47^{\mathrm{b}}$ & $2817 \pm 82^{\mathrm{a}}$ & $2582 \pm 65^{\mathrm{a}}$ & $3797 \pm 76^{\mathrm{a}}$ & $990 \pm 65^{\mathrm{a}}$ & $5.07 \pm 0.9^{\mathrm{a}}$ & $71.85 \pm 6^{\mathrm{a}}$ \\
YOF & $5012 \pm 31^{\mathrm{c}}$ & $2218 \pm 67^{\mathrm{b}}$ & $2699 \pm 21^{\mathrm{b}}$ & $3088 \pm 72^{\mathrm{b}}$ & $765 \pm 54^{\mathrm{b}}$ & $5.24 \pm 0.6^{\mathrm{a}}$ & $75.23 \pm 9^{\mathrm{a}}$ \\
\hline
\end{tabular}

Values are analyzed in triplicated and represented as (Means \pm SD) with different superscript down the column being significantly different $(\mathrm{P}<0.05)$.

White flesh odourless fufu flour (WOF)

Yellow flesh odourless fufu flour (YOF) 
4. Functional properties of white and yellow flesh odourless fufu flours produced using NSPRI technology

Table 3 shows the functional properties of the white and yellow flesh odourless fufu flours. The loose bulk densities of the flours are 0.39 and $0.42 \mathrm{~g} / \mathrm{cm}^{3}$ for WOF and YOF respectively. A similar trend was observed in the water absorption index and swelling power of the flours. The water absorption indexes of the flours are $217.97 \%$ (WOF) and $301.11 \%$ (YOF) while swelling power turned out to be $4.31 \%$ (WOF) and $5.13 \%$ (YOF). From the results obtained, the values were higher in YOF than in WOF for loose bulk density, water absorption index and swelling power of the flours. While a dissimilar trend was observed in dispersibility, starch solubility and packed bulk density, with WOF having low values than YOF.
5. Microbial load of white and yellow flesh odourless fufu flours produced using NSPRI technology

From the results shown above, it was observed that the dried processed had a lowered microbial load which is at safe level and no coliform bacteria was observed on the agar plates after inoculation of the serially diluted flour samples. Also the result indicates that the total plate count and mold count of sample YOF is a bit higher than those of WOF with all sample having very less microbial load, less than $100,000 \mathrm{cfu} / \mathrm{g}(5 \mathrm{Log})$.

6. Sensory evaluation of white and yellow flesh odourless fufu flours produced using NSPRI technology

Table 5 shows sensory evaluation scores for the cooked samples -WOF and YOF. There were significant differences $(\mathrm{P}<0.05)$ in the ratings given by the panelists for all the indexes evaluated.

Table 3. Functional properties of white and yellow flesh odourless fufu flours

\begin{tabular}{lcccccc}
\hline Parameters & $\begin{array}{c}\text { Loose Bulk } \\
\text { Density } \\
\left(\mathbf{g} / \mathbf{c m}^{\mathbf{3}}\right)\end{array}$ & $\begin{array}{c}\text { Packed Bulk } \\
\text { Density } \\
\left(\mathbf{g} / \mathbf{c m}^{\mathbf{3}}\right)\end{array}$ & $\begin{array}{c}\text { Water } \\
\text { Absorption } \\
\text { Index }(\boldsymbol{\%})\end{array}$ & $\begin{array}{c}\text { Dispersibility } \\
\mathbf{( \% )}\end{array}$ & $\begin{array}{c}\text { Swelling } \\
\text { Power }(\boldsymbol{\%})\end{array}$ & $\begin{array}{c}\text { Starch } \\
\text { Solubility } \\
\text { Index }(\boldsymbol{\%})\end{array}$ \\
\hline WOF & $0.39 \pm 0.02$ & $0.49 \pm 0.02$ & $217.97 \pm 4.72$ & $69.00 \pm 1.41$ & $4.31 \pm 4.62$ & $8.50 \pm 0.49$ \\
YOF & $0.42 \pm 0.03$ & $0.48 \pm 0.02$ & $301.11 \pm 5.12$ & $59.00 \pm 2.94$ & $5.13 \pm 0.21$ & $6.18 \pm 0.15$ \\
\hline
\end{tabular}

Values are analyzed in triplicated and represented as (Means \pm SD) with different superscript down the column being significantly different $(\mathrm{P}<0.05)$.

White flesh odourless fufu flour (WOF)

Yellow flesh odourless fufu flour (YOF)

Table 4. Microbial load of Odourless fufu flours in WOF and YOF

\begin{tabular}{lccc}
\hline Flour & \multicolumn{3}{c}{ Samples } \\
\cline { 2 - 4 } & Total Plate Count $(\mathbf{c f u} / \mathbf{g})$ & Total Mold Count & Total Coliform Count \\
\hline WOF & $4.6 \log$ & $3.3 \log$ & 0 \\
YOF & $4.82 \log$ & $3.30 \log$ & 0 \\
\hline
\end{tabular}

*Samples were taken and analyzed in triplicates and results are given as a mean of these triplicates.

White flesh odourless fufu flour (WOF)

Yellow flesh odourless fufu flour (YOF)

Table 5. Sensory evaluation of white and yellow flesh odourless fufu flours

\begin{tabular}{lcc}
\hline Sensory Properties & WOF & YOF \\
\hline Appearance & $7.85 \pm 0.15^{\mathrm{a}}$ & $5.91 \pm 0.20^{\mathrm{b}}$ \\
Colour & $7.62 \pm 0.08^{\mathrm{a}}$ & $6.52 \pm 0.19^{\mathrm{b}}$ \\
Aroma & $7.44 \pm 0.14^{\mathrm{a}}$ & $7.46 \pm 1.05^{\mathrm{a}}$ \\
Taste & $6.32 \pm 1.15^{\mathrm{b}}$ & $6.35 \pm 0.84^{\mathrm{b}}$ \\
Overall acceptability & $7.85 \pm 0.34^{\mathrm{a}}$ & $6.58 \pm 0.26^{\mathrm{b}}$ \\
\hline
\end{tabular}

Values are analyzed in triplicated and represented as (Means \pm SD) with different superscript down the column being significantly different $(\mathrm{P}<0.05)$.

White flesh odourless fufu flour (WOF)

Yellow flesh odourless fufu flour (YOF) 
The mean score were WOF $(7.85,7.62,7.44,6.32,7.85)$ and YOF $(5.61,6.52,7.46,6.35,6.58)$ for appearance, colour, aroma, taste and overall acceptability respectively. It was observed that the panelists liked both samples. However, the appearance and colour of WOF was preferred, while the aroma and taste of YOF was preferred to that of WOF. In terms of overall acceptability, white flesh odourless fufu flour (WOF) was rated higher and therefore most preferred by the panelists.

\section{DISCUSSION}

Cassava is generally known to be a calorie-rich food that contains carbohydrates and other key minerals and vitamins. Uchechukwu et al., (2015) similarly reported $83.63 \%$ carbohydrate content of some cassava variety. This makes cassavas suitable for starch production and the values reported in this study are within the range of values also reported by Alamu et al., 2017. The moisture content, which is the amount of residual water in the sample were low and the lower the initial moisture content of a product, the better the storage stability of the product. The moisture content of the odourless fufu flours were below the recommended limits of $14 \%$ required for storage and stability even at ambient temperature (Simsek, 2015). The lower the initial moisture content, the higher the efficiency of the drying method (Sanni et al., 2006). Furthermore, the crude fibre content values range between 1.5 -3.5\% which agrees with the findings of Gil and Buitrago, (2002).

The cyanide concentration of WOF was slightly higher than that of YOF. Although, the cyanide concentrations of both samples were less than 50-100 $\mathrm{mg} \mathrm{HCN} / \mathrm{kg}$ in fresh root to Eleazu and Eleazu (2012) and FAO (2019), and is therefore regarded as safe for consumption. For vitamin $\mathrm{c}$ concentration, it was observed that the YOF had a significantly higher $(\mathrm{P}<0.05)$ concentration than WOF. This same trend was observed in the concentration of total carotenoid. It was obvious that the yellow flesh cassava specie investigated had significantly higher vitamin $\mathrm{c}$ and total carotenoid quantities than the white flesh, thus this may confer antioxidant potential. Several factors including starch chain length distribution, granule size, of amylopectin chain and amylose content usually influence the peak viscosity of starch rich substances. Generally, low amylose starch displays high peak viscosity. Breakdown viscosity a measure of paste stability (Maziya et al., 2004), measures the susceptibility of the starch granule to disintegrate during heating. The results obtained were similar to the reports by Sanni et al., (2006) for peak viscosity. Final viscosity; the most commonly used parameter to determine the quality of a starch-based sample. It indicates the ability of the material to form gel after cooking. From the study, it was highest for WOF and was also within the range of values reported by Sanni et al., (2006), Nkououdou and Essia (2017) and Oyeyinka et al., (2019) for final viscosity of dried varieties of cassava samples. However, for pasting temperature, the values previously reported by Sanni et al., (2006) were lower than the values obtained in this study. Furthermore, the pasting temperature which represents the temperature at which the sample will cook were $71.85{ }^{\circ} \mathrm{C}$ (WOF) and $75.23{ }^{\circ} \mathrm{C}$ (YOF). These temperatures were within the range of values $\left(60-80{ }^{\circ} \mathrm{C}\right)$ previously reported by (Ezeocha and Okafor, 2016; Nkououdou and Essia (2017); Oyeyinka et al., 2019). Previous studies have indicated that a high water absorption capacity is attributed to a loose structure of starch polymers however low value indicates the compactness of the molecular structure (Adebowale, et al., 2005). This therefore implies that YOF with a higher water absorption capacity that WOF possesses a loose structure of starch polymers. On the otherhand, the higher the dispersibility the better the flour reconstitutes in water as dispersibility which is a measure of the reconstitutability of the flour in water (Sanni et al., 2006). This ability is therefore favourable in WOF with a higher dispersibility than YOF. Although, the values obtained in this study were close to the range of values reported by Sanni et al., (2006).

It was observed that drying of processed fufu kept the microbial load to a safe level and no coliform bacteria was observed on the agar plates after inoculation of the serially diluted flour samples, this indicates good processing practice and handling down the processing line. The result above indicates that the total plate count and mold count of sample YOF is a bit higher than those of WOF, this maybe be linked to a higher nutritional content present in the YOF flour. From the result, it can be observed that all the flour samples contain very less microbial load, less than $100,000 \mathrm{cfu} / \mathrm{g}(5 \mathrm{Log})$, which is in line with the report given by Prabhakar and Mallika (2014) on dried foods.

On acceptability of the WOF and YOF, It was observed that the panelists liked both samples. However, the appearance and colour of WOF was preferred, while the aroma and taste of YOF was preferred to that of WOF. In terms of overall acceptability, white flesh odourless fufu flour (WOF) was rated higher and therefore most preferred by the panelists.

In conclusion, drying is mostly used to preserve cassava, in other to reduce post-harvest loss and in the processing of cassavas; the drying technique usually has 
an effect on the chemical and sensorial properties of the resultant fufu dough. The results obtained in this study proved that the NSPRI Multi-crop dryer was quite efficient in reducing the moisture content of the white and yellow flesh odourless fufu flours to a minimum that would be favourable for a long storage period. Also, the drying process of the flour samples kept the microbial load to a safe level and free from coliform bacteria. This thus indicates good processing and handling practices. in addition, the sensory evaluation showed that the white and yellow flesh odourless fufu samples were generally liked by the panelists, but for overall acceptability, the white flesh odourless fufu was highly rated and most preferred.

\section{REFERENCES}

Achi, O.K. and N.S. Akomas. 2006. Comparative assessment of fermentation techniques in the processing of fufu, a traditional fermented cassava product. Pakistan Journal of Nutrition, 5(3):224-229.

Awoyale, W., L.O. Sanni, T.A. Shittu, and M.O. Adegunwa, 2015. Effect of varieties on the functional and pasting properties of biofortified cassava root starches. Journal of Food Measurement and Characterization, 9(2):225-232.

Alamu, E.O.,B.Maziya-Dixon and A.G.Dixon, 2017. Evaluation of proximate composition and pasting properties of high quality cassava flour (HQCF) from cassava genotypes (Manihot esculenta Crantz) of $\beta$ carotene-enriched roots. LWT, 86: 501-506.

Eguono, I., 2015. A look at Cassava production in Nigeria. International Journal of Agricultural Sciences, 5(5), pp.818-819.

Association of Official Analytical Chemists (AOAC), Official Methods of Analysis International 18TH Edition, International 2005. Gaithersburg, Maryland USA.

Ayetigbo, O., S. Latif, A. Abass, and J. Müller, 2018. Comparing characteristics of root, flour and starch of biofortified yellow-flesh and white-flesh cassava variants, and sustainability considerations: a review. Sustainability, 10(9):3089.

Ayetigbo, O. S.Latif , A., Abass and J. Müller, 2019. Preparation, optimization and characterization of foam from white-flesh and yellow-flesh cassava (Manihot esculenta) for powder production. Food Hydrocolloids, 97: 105205.https://doi.org/10.1016/j.foodhyd.2019.105205

Bamidele, O.P., M.B. Fasogbon, D.A. Oladiran and E.O. Akande, 2015. Nutritional composition of fufu analog flour produced from Cassava root (Manihot esculenta) and Cocoyam (Colocasia esculenta) tuber. Food science \& nutrition, 3(6):597-603.

Chukwu, E.C. 2020. Development of a Plant-Based Frozen Dessert Derived from Taro (Colocasia Esculenta) (Doctoral dissertation, North Carolina Agricultural and Technical State University).

Ceballos, H., N. Morante, T.Sánchez, D. Ortiz, I. Aragon, A.L. Chávez, M.Pizarro, F Calle, and D. Dufour, 2013.
Rapid cycling recurrent selection for increased carotenoids content in cassava roots. Crop Science, 53(6): 2342-2351.

Chávez, A. L., J.M. Bedoya, T.Sánchez, C. Iglesias, H. Ceballos, and W.Roca, 2000. Iron, carotene, and ascorbic acid in cassava roots and leaves. Food and Nutrition Bulletin, 21(4): 410-413.

Ekunseitan, O. F., A. O. Obadina, O. P. Sobukola, A. M. Omemu, M. O. Adegunwa, O. E. Kajihausa, et al. 2017. Nutritional composition, functional and pasting properties of wheat, mushroom, and high quality cassava composite flour. Journal of food processing and preservation, 41(5):13150.

Eleazu, C. O. and K. C. Eleazu, 2012. Determination of the proximate composition, total carotenoid, reducing sugars and residual cyanide levels of flours of 6 new yellow and white cassava (Manihot esculenta Crantz) varieties. American Journal of Food Technology, 7(10):642-649.

Ezeocha, C. V. and J. C. Okafor, 2016. Evaluation of the chemical, functional and pasting properties of starch from trifoliate yam (Dioscorea dumetorum) landraces. Eur. J. Adv. Res. Biol. Life Sci, 1-4.

FAO. 2019. Rome, Italy: Food and Agricultural Organisation of the United Nations. (accessed 19 November).

Farhat, I. A., T. Oguntona, and R. J. Neale, 1999. Characterisation of starches from West African yams. Journal of the Science of Food and Agriculture, 79(15):2105-2112.

Galani, J. H., J. S.Patel, N. J. Pateland, J. G. Talati, 2017. Storage of fruits and vegetables in refrigerator increases their phenolic acids but decreases the total phenolics, anthocyanins and vitamin $\mathrm{C}$ with subsequent loss of their antioxidant capacity. Antioxidants, 6(3): 59.

Gegios, A., Amthor, R., Maziya-Dixon, B., Egesi, C., Mallowa, S., Nungo, R and Manary, M. J. 2010. Children consuming cassava as a staple food are at risk for inadequate zinc, iron, and vitamin $\mathrm{A}$ intake. Plant Foods for Human Nutrition, 65(1): 64-70.

Gil, J. L., and A. J. A.Buitrago, 2002. La Yuca En La Alimentacion Animal. In La Yuca En El Tercer Milenio: Sistemas Modernos De Producción, Procesamiento, Utilización Y Comercialización. Cali, Colombia: Centro Internacional De Agricultura Tropical; Ospina, B., Ceballos, H., Eds.; Columbia: CIAT, 527-569.

Gu, B., Q., Yao, K. Li, and S. Chen, 2013. Change in physicochemical traits of cassava roots and starches associated with genotypes and environmental factors. Starch Stärke, 65(3-4):253-263.

Harouna, D. V., P. B. Venkataramana, Matemu, A. O. and P. A. Ndakidemi, 2019. Assessment of Water Absorption Capacity and Cooking Time of Wild Under-Exploited Vigna Species towards their Domestication. Agronomy, 9(9): 509. 
Kulkarni, K. D., D. N. Kulkarni and U. M. Ingle, 1991. Sorghum malt-based weaning food formulations Sorghum malt-based weaning food formulations: Preparation, functional properties, and nutritive value. Food and Nutrition Bulletin, 13(4): 322-327.

Maziya-Dixon, B., A. G. Dixon and A. R. A. Adebowale, 2007. Targeting different end uses of cassava: genotypic variations for cyanogenic potentials and pasting properties. International journal of food science \& technology, 42(8): 969-976.

Montagnac, J. A., C. R. Davis, and S. A. Tanumihardjo, 2009. Nutritional value of cassava for use as a staple food and recent advances for improvement. Comprehensive reviews in food science and food safety, 8(3):181-194.

Nkoudou, N. Z. and J. J. N. Essia, 2017. Cyanides reduction and pasting properties of cassava (Manihot Esculenta Crantz) flour as affected by fermentation process. Food and Nutrition Sciences, 8(3): 326-333.

Nweke, F. I. 1994. Cassava processing in sub-Saharan Africa: The implications for expanding cassava production. Outlook on agriculture, 23(3):197-205.

Ogungbemi K., S. E. Atawodi, I. D. Taiwo, I. O., Tomilayo, I. F. Funmilayo, and A. K. Adebisi, 2017. Performance characteristics of male wistar rats fed graded levels of stored powdered Corchorus olitorius. International Journal, 3(2): 28.

Okafor, N.,B. Ijioma, and C.Oyolu, 1984. Studies on the microbiology of cassava retting for foo-foo production. Journal of Applied Bacteriology, 56(1):1-13.

Owolarafe, O. K., B. O. Adetifa, A. C. Oyekanmi, T. G. Lemikan, and T. M. Samuel, 2018. Assessment of fufu production technologies in Ogun State, Nigeria. Arid Zone Journal of Engineering, Technology and Environment, 14(4): 547-558.

Oyeyinka, S. A., S. Singh, P. O., Adebola, A. S. Gerrano and E. O. Amonsou, 2015. Physicochemical properties of starches with variable amylose contents extracted from bambara groundnut genotypes. Carbohydrate polymers, 133:171-178.

Oyeyinka, S. A., A. A. Adeloye, S.A. Smith, B.O. Adesina and F.F.Akinwande, 2019. Physicochemical properties of flour and starch from two cassava varieties. Agrosearch, 19(1): 28-45.
Prabhakar. K and E.N. Mallika, 2014. Dried Foods. Encyclopedia of Food Microbiology (Second Edition), pp. 574-576.

Doi: https://www.sciencedirect.com/science/article/pii/b978-012-384730-0.00085-9

Sanni, L. O., A.A. Adebowale, T.A. Filani, O.B. Oyewole, and A. Westby, 2006. Quality of flash and rotary dried fufu flour. Journal of Food, Agriculture and Environment, 4(3\&4): 74-78.

Simsek, S. 2015. Wheat quality and carbohydrate research. Flour analysis. http://www.ndsu.edu/faculty/simsek/wheat/flour.html\# [Accessed: 29 April 2021].

Singh, N., M. Kaur, and K. S. Sandhu, 2005. Physicochemical and functional properties of freeze-dried and oven dried corn gluten meals. Drying technology, 23(4): 975-988.

Uchechukwu-Agua, A. D., O. J. Caleb, M. Manley and U. L. Opara, 2015. Effects of storage conditions and duration on physicochemical and microbial quality of the flour of two cassava cultivars (TME 419 and UMUCASS 36). CyTAJournal of food, 13(4): 635-645.

Vimala, B., R. Thushara, and B. Nambisan, 2010, November. Carotenoid retention in Yellow- fleshed Cassava during processing. In Proceedings of the 15th Triennial International Society for Tropical Root Crops (ISTRC) Symposium, Lima, Peru (pp. 2-6).

.De Carvalho, L. M. J., P. B., Gomes, R. L. de Oliveira Godoy, S.Pacheco, do Monte, P. H. F. , J. L. V. de Carvalho, and S. R. R. Ramos, 2012. Total carotenoid content, $\alpha$-carotene and $\beta$-carotene, of landrace pumpkins (Cucurbita moschata Duch): A preliminary study. Food Research International, 47(2): 337-340.

Güngör, E. and N.Gökoğlu, 2010. Determination of microbial contamination sources at a Frankfurter sausage processing line. Turkish Journal of Veterinary and Animal Sciences, 34(1): 53-59.

Saadoudi, M., L. Hambaba, M. Abdeddaim, A. Lekbir, A. Bacha, S. Boudraa, and S. Zidani, 2017. Nutritional composition, physical properties and sensory evaluation of biscuit produced from jujubes (Fruits of Zizyphus lotus L.). Annals. Food Science and Technology, 18 :(1-3). 